\title{
AN EFFICACY OF ZOBE DAM FOR HYDROELECTRICITY GENERATION IN KATSINA STATE, NIGERIA
}

\author{
I. Nuhu ${ }^{1, *}$ and H. Abdulsalam² \\ 1, 2, Centre for Renewable Energy Research Umaru Musa Yar'AduA University, Katsina, Katsina \\ STATE. NIGERIA \\ Email addresses: ${ }^{1}$ ibrahim.nuhu@umyu.edu.ng, 2 hassan.daura@umyu.edu.ng
}

\begin{abstract}
The quest for other alternative and sustainable energy prompted the feasibility assessment of Zobe dam meant for irrigation to produce electricity; In this write-up the scheme is designed to operate with two turbines; turbine $T_{1}$ to operate all year round to take account of the irrigation need downstream, The second turbine $T_{2}$ will operate on a spill discharge, and to be available for four months with a generation capacity of $0.969 \mathrm{MW} . \mathrm{T}_{1}$ is expected to discharge $55,500,000 \mathrm{~m}^{3}$ within six months to cater for irrigation need with an average discharge rate of $3.6 \mathrm{~m}^{3} / \mathrm{s}$, it was found that, the dam has the potential to generate a minimum $0.671 \mathrm{MW}$ all year round and a maximum of 1.5MW of power during Peak discharge period. The scheme was designed with minimum modification of the existing infrastructure at site which translate to minimum cost implication in construction, system operation and maintenance.
\end{abstract}

Keywords: Economic transformation, Energy, hydropower, Irrigation farming, Zobe dam,

\section{INTRODUCTION}

It is a known fact that electricity supply in most part of the country is inadequate to cater for Nigerians need [1]. The current electric power generation falls below $4000 \mathrm{MWw}$ wich is $30 \%$ of the projected energy demand in the country. Inadequate fuel supply couples with security challenges are some of the reasons why the generation falls below $50 \%$ as more than $80 \%$ of the installed generation capacity are thermal power plants $[2,3]$. Apart from technical challenges encountered during power transmission and distribution, the issue of losses cannot be overlooked which account a waste of significant percentage of energy along the energy production chain.

The Zobe Dam situated on the coordinates $12^{0} 21$ $37.69^{\prime \prime} \mathrm{N} 7^{0} 2753.98^{\prime \prime} \mathrm{E}$ is in Dutsin-Ma local government area of Katsina State in the northern part of Nigeria, an earth-fill structure with a height of $19 \mathrm{~m}$ and a total length of $2,750 \mathrm{~m}$. The dam has a storage capacity of 177 million cubic meters and irrigation potential of 8,000 hectares. Zobe Dam was conceived in the late 1970 s and was planned to supply $50 \%$ of drinking water to Katsina state while also supporting irrigation farming in the Dutsinma area and nearby towns and villages along the dam spillway discharge. The dam was a Federal Urban Water Project completed in 1983 [4].

Hydro is a clean energy source and best grade among all renewable energy resources $[5,6]$ with less negative environmental impact, one of the cheapest source of energy [7], it's the first source of energy matured and relatively well understood by Nigerians. Nigeria as a nation is blessed with both human and Natural resource among which is vast arable land for different agricultural activities, which our land can support all year round. These among others are some of the reason why most earth dams were built across the country, and in most cases built for dual purposes; for agricultural activities and for domestic consumption. As Nigeria's need for energy is ever increasing by the day like most of the developing nations due to rapid population and developmental growth [8] there is need for the

* Corresponding author, tel: +234 - 803-575-8990 
country to search and harness the abundant untapped energy resources [7] to meet up the wide gap between the need and the generation.

There is also environmental concern on the way and manner of how the teaming populations continue to deforest the existing flora just to meet the primary source of energy [8]. It is estimated that over $80 \%$ of primary energy need in Nigeria is being met from trees [13]. These among others are what prompted the need for other sustainable and renewable sources of energy. Such as wind, solar and small hydro that can easily be managed by local communities [1] and can adequately meet the energy need for small scale industries .In addition to providing employment opportunities for our teeming youth it will also checkmate the issue of environmental degradation for security and positive economic transformation in the country. According to [1] and [8] Small hydro scheme if design as a mini grid to power the nearby communities could reduce the transmission and distribution losses drastically. There was an earlier study of the potentials of Zobe dam as reported by ICRC [4] the study found that the Dam has a capacity of $290.3 \mathrm{~kW}$; with design discharge of $7.51 \mathrm{~m}^{3} / \mathrm{s}$ for each turbine; and three units of $97 \mathrm{~kW}$ capacities each proposed to utilize the entire range of discharges available from the dam. However it requires series of the Dam modification and therefore capital intensive. This concept is aimed to reduce capital expenditure to the barest minimum and to generate energy without tempering with the existing dam infrastructure at site, generating energy to communities and serving its primary objective as designed.

\section{METHODOLOGY}

\subsection{Estimation of water inflow to the dam}

Zobe dam like most of the dams built for irrigation scheme supplies water to its beneficiaries by gravity, the irrigation farmers uses the water for various irrigation activities and some few farmers who operates fishery farms downstream. In this write-up attempt was made to assess the feasibility of using that water to turn a turbine before the water is acted upon by gravity to take its course downstream.

It started by looking at the dam catchment area; the Karaduwa River that flows through narrow formed valleys, deep cut valleys, and partly minor sandy floodplains [4] and estimated the average inflow to the dam to find the available volume of water that could be used by the irrigation farmers downstream which will equally used by the scheme. The annual inflow to the dam can be obtained using equation 1 .

$$
Q=C I A
$$

Where; $\mathrm{I}=$ Average rainfall intensity $\mathrm{mm} /$ Year; $\mathrm{A}$ $=$ Catchment area $\mathrm{m}^{2} ; \mathrm{C}=$ Runoff coefficient (taking Lawns as catchment area terrain see Table 1)

Table 1: A chart of train and its corresponding runoff coefficient. Source: [9].

\begin{tabular}{ll}
\hline Ground cover & Runoff coefficient, \\
\hline Lawns & C \\
Forest & $0.05-0.35$ \\
Cultivated Land & $0.05-0.25$ \\
Meadow & $0.08-0.41$ \\
Parks, cemeteries & $0.1-0.5$ \\
Pasture & $0.1-0.25$ \\
Residential areas & $0.12-0.62$ \\
Business and Industrial & $0.3-075$ \\
areas & $0.5-0.95$ \\
Asphalt streets & $0.7-0.95$ \\
Bricks streets & $0.7-0.85$ \\
Roofs & $0.75-0.95$ \\
\hline
\end{tabular}

The proposed Zobe Hydroelectric Power (HEP) plant is design to operates on two schemes; Scheme I to operates with lower flow rate adequate to cater for irrigation needs, it is expected to discharge $55,500,000 \mathrm{~m}^{3}$ of water a volume estimated to cater for irrigation [4] within a period of 6months, the scheme will run a turbine that will be available all year round; within the irrigation period is estimated to discharge sufficient volume for irrigation at constant discharge rate. While scheme 11 which will operate at higher flow rate will serve a dual purpose;

1- To serve the same purpose as spill way within the period of rainy season five month (from June to October)

2- To run a scheme of higher flow rate using a discharge tube of flow rate capacity of $5.25 \mathrm{~m}^{3} / \mathrm{s}$

The design is based on the existing infrastructure at site; the discharge pipes are used as penstocks one of the discharge pipes of volumetric flow of $5.25 \mathrm{~m}^{3}$ is used as penstock for turbine $T_{2}$ while the second penstock was modified to discharge $3.6 \mathrm{~m}^{3}$ to inlet of turbine $T_{1}$.

Zobe Dam has $2309 \mathrm{~km}^{2}$ as catchment area which comprises Karadua and Bunsuru, The Karadua River flows through narrow formed valleys, deep cut valleys, and partly minor sandy floodplains [4]. The annual average inflow to the dam computed using equation 1 .

Vol. 39, No. 4, October 2020

1233 
Stood as three hundred and twenty three million cubic meters $323.26 \times 10^{6} \mathrm{~m}^{3}$; Where $(400 \mathrm{~mm} /$ year average I at Katsina Fig 1)[11]; $\left(2309 \times 10^{6} \mathrm{~m}^{2}\right)$ as Catchment area [4], and 0.05 as least run-off coefficient for Lawns and Cultivated land area.

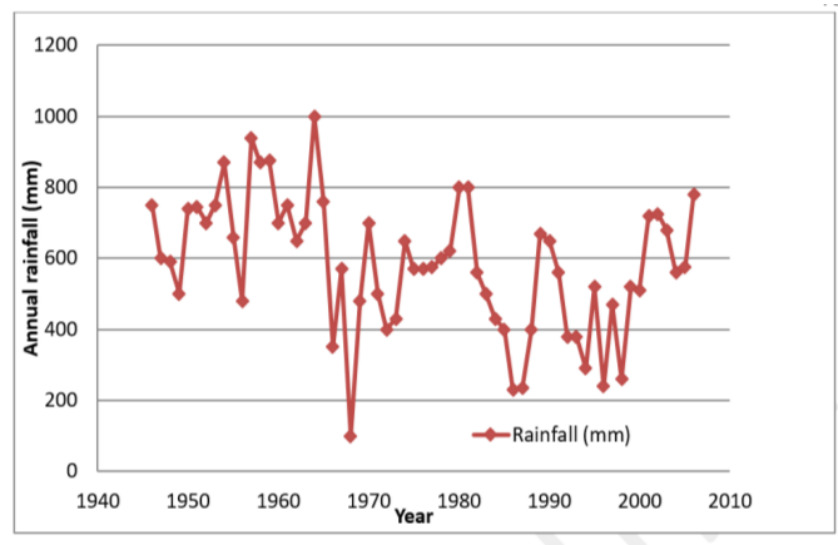

Figure 2: A graph showing 60 years of rainfall pattern of Katsina area. Source: [10]

\subsection{Assessment of the Hydropower Potentials of the Zobe Reservoir}

Hydropower Potential of a dam is solely dependent on the available gross head, and Flow rate the theoretical hydropower of a hydropower scheme can be computed using equation 2 the gross hydropower GHPs. The power available from a hydropower scheme is dependent on the volume flowing in the system and its drop in height. The relationship is expressed by the commonly used power equation

$$
P=\operatorname{e\rho gQH}
$$

Where GHP or $\mathrm{P}$ is power (Watts), $\mathrm{e}$ is the overall efficiency $(\%), \rho$ is the density of water $(1,000$ $\left.\mathrm{kg} / \mathrm{m}^{3}\right), \mathrm{g}$ is the acceleration due to gravity (9.81 $\left.\mathrm{m} / \mathrm{s}^{2}\right), \mathrm{Q}$ is the water discharge expected to pass through the turbine $\left(\mathrm{m}^{3} / \mathrm{s}\right)$, and $\mathrm{H}$ is the gross head (m).

\subsection{Estimating the hydropower potential of the SHP.}

Based on the estimated live capacity of $177,000,000 \mathrm{~m}^{3}$ the estimated discharge to the hydropower plant in a day is based on irrigation need downstream stood at $177,000,000 / 365$.The proposed hydropower plant which is expected to run on two schemes is computed as;

\subsubsection{Scheme 1}

To run all year round at a discharge rate adequate to cater for irrigation need downstream, Water need for irrigation is estimated at 55,500,000 $\mathrm{m}^{3}$ [4] thus the daily irrigation need is $308,333 /$ daywhich covers a period of six month November- April (6 month)Thus the flow rate is $3.6 \mathrm{~m}^{3} / \mathrm{s}$ and a power potential is obtained using equation (2). $\mathrm{PW}_{1}$ $=671,004 \mathrm{~W}$

\subsubsection{Scheme 2}

The system here will use two turbines; in addition to $T_{1}$ which will be available all year round, a turbine $T_{2}$ will join in, in July to operate at a higher discharge to take advantage of a spill discharge with a volumetric flow of $5.2 \mathrm{~m}^{3} / \mathrm{s}$. with an average head of 19 meters using equation 2the estimated power by the turbine is $969,228 \mathrm{~W}$.

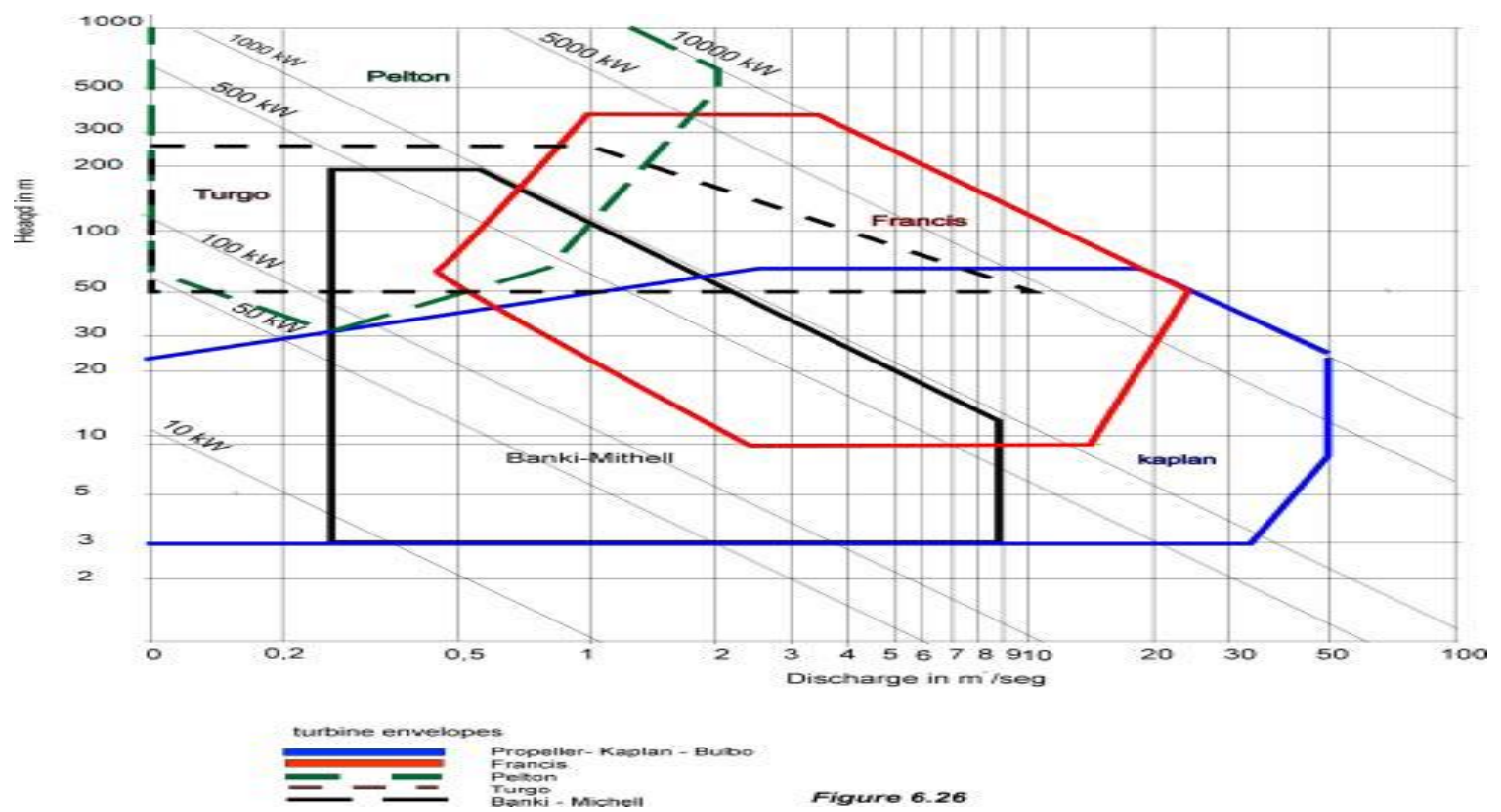

Figure 3: A monogram for turbine selection based on flow rate, Head and power. Source:[12] 


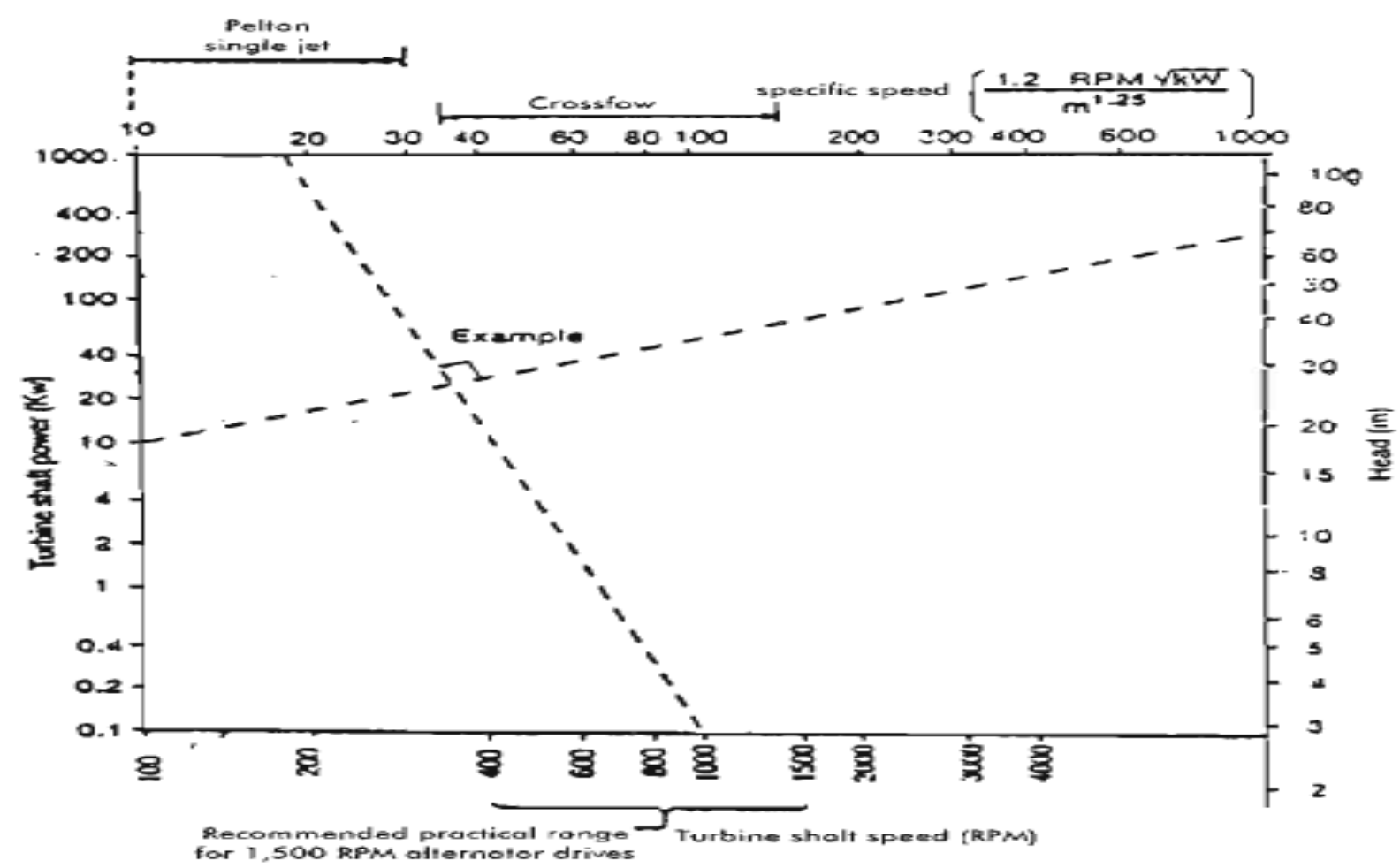

Figure 4: A monogram for selecting a hydro turbine with corresponding specific speed Source: [12].

The total power potential within that period is the sum of generated power of the two schemes.

$\mathrm{PW}_{1}+\mathrm{PW}_{2}=1,640,232 \mathrm{~W}$.

Discharge available using the existing two penstocks $\left(10.5 \mathrm{~m}^{3} / \mathrm{s}\right)$, Penstock $\mathrm{P} 1$ couple to turbine $\mathrm{T} 1$ has a volumetric flow rate of $5.2 \mathrm{~m} 3 / \mathrm{s}$ while penstock P2 for turbine T2 was fitted with an adapter to accommodate a discharge pipe of $3.6 \mathrm{~m} 3 / \mathrm{s}$ volumetric flow rate.
Considering the volumetric flow rate and low Head, Kaplan reaction turbine of $0.7 \mathrm{~mW}$ and $1 \mathrm{~mW}$ is selected as $T_{1}$ and $T_{2}$ respectively (see Figure 2 ).

\section{RESULT AND DISCUSSION}

Total volume of water used by the schemes $=165,888,000 \mathrm{~m}^{3}$ (See table 1). The Percentage volume of inflow to that used by the scheme in a year stood at average of $\left(165.888 \times 10^{6} \mathrm{~m}^{3} / 323.26 \times 10^{6} \mathrm{~m}^{3}\right) \times 100=51.3 \%$.

Table 1: Power Estimation and availability of the turbines.

\begin{tabular}{lllllll}
\hline \multirow{2}{*}{$\mathrm{S} / \mathrm{N}$} & \multirow{2}{*}{ Month } & \multicolumn{2}{l}{ Power $(\mathrm{W}) *$} & \multicolumn{2}{l}{ Total } & Volumetric flow rate \\
\cline { 3 - 6 } $\mathrm{T}_{1}(\mathrm{~W})$ & $\mathrm{T}_{2}(\mathrm{~W})$ & $\left(\mathrm{T}_{1+} \mathrm{T}_{2}\right) \mathrm{W}$ & $\begin{array}{l}\text { Volume discharged in a } \\
\text { month }\left(\mathrm{m}^{3}\right)\end{array}$ \\
\hline 1 & January & 671,004 & 0.0000 & 671,004 & $3.6 \mathrm{~m} 3 / \mathrm{s}$ & 9331200 \\
2 & February & 671,004 & 0.0000 & 671,004 & $3.6 \mathrm{~m} 3 / \mathrm{s}$ & 9331200 \\
3 & March & 671,004 & 0.0000 & 671,004 & $3.6 \mathrm{~m} 3 / \mathrm{s}$ & 9331200 \\
4 & April & 671,004 & 0.0000 & 671,004 & $3.6 \mathrm{~m} 3 / \mathrm{s}$ & 9331200 \\
5 & May & 671,004 & 0.0000 & 671,004 & $3.6 \mathrm{~m} 3 / \mathrm{s}$ & 9331200 \\
6 & June & 671,004 & 0.0000 & 671,004 & $3.6 \mathrm{~m} 3 / \mathrm{s}$ & 9331200 \\
7 & July & 671,004 & 969,228 & $1,640,232$ & $8.8 \mathrm{~m} 3 / \mathrm{s}$ & 22809600 \\
8 & August & 671,004 & 969,228 & $1,640,232$ & $8.8 \mathrm{~m} 3 / \mathrm{s}$ & 22809600 \\
9 & September & 671,004 & 969,228 & $1,640,232$ & $8.8 \mathrm{~m} 3 / \mathrm{s}$ & 22809600 \\
10 & October & 671,004 & 969,228 & $1,640,232$ & $8.8 \mathrm{~m} 3 / \mathrm{s}$ & 22809600 \\
11 & November & 671,004 & 0.0000 & 671,004 & $3.6 \mathrm{~m} 3 / \mathrm{s}$ & 9331200 \\
12 & December & 671,004 & 0.0000 & 671,004 & $3.6 \mathrm{~m} 3 /$ & 9331200 \\
\hline
\end{tabular}

*Power potential estimated using eqn. 2 
Table 2: Zobe Dam Technical design data.

\begin{tabular}{lll}
\hline Design Data & Quantity & Unit \\
\hline Dam storage volume & $177,000,000$ & $\mathrm{~m}^{3}$ \\
Available Head & 19 & $\mathrm{~m}$ \\
Length of main earth filled dam & $2,750.00$ & $\mathrm{~m}$ \\
Reservoir of the dam is & 500 & Hectares \\
Outlet discharge pipes & 10.8 & $\mathrm{~m}^{3}$ \\
Length of spill way 1 & 100 & $\mathrm{~m}$ \\
Length of spill way 2 & 76 & $\mathrm{~m}$ \\
Spill way Discharge (max) & 1087 & $\mathrm{~m}^{3} / \mathrm{s}$ \\
\hline
\end{tabular}

\subsection{Discussion of Results}

The power is computed from the two Turbine $T_{1}$ and $T_{2}$ that were installed, the scheme is intended to use the discharge pipes as penstock, so the use of new penstock is eliminated, the only cost implication will be that of the turbine assembly and power House accessories From table 2 It can be seen that, the dam has the potential of providing $671 \mathrm{~kW}$ from November to June and $1640 \mathrm{~kW}$ within the next four month, though the dam could provide more power as reported by[4] but the cost implication is high because it requires some modifications on the existing structures, its envisage that such design will be more applicable to dams with similar features, if such is embraced it will go a long way in promoting hydro, checkmating the social and environmental issues associated to dam construction, operation and maintenance. Since the scheme requires no expansion which in most cases requires resettlement of nearby communities. The immediate communities can benefit from the facility with minimal cost implication to support their energy need. This type of scheme needs very short time to be realized once it's conceived. Unlike the conventional hydro scheme which in most cases takes not less than two years to actualized.

\section{REFERENCES}

[1] Aribisala, J. O. and Sule, B. F."Seasonal Operation of a Reservoir Hydropower System", Technical Transactions Nigerian Society of Engineers, NSE, 33 (2), 1998, pp. 1-14

[2] Nigeria Energy sector overview"https://www.usaid.gov> powerafrica accessed on July 20,2020

[3] Manohar K. and Adeyanju A. A. "Hydro Power Energy Resources in Nigeria", Journal of
Engineering and Applied Sciences, 4 (1), 2009, pp 68-73

[4] Zobe dam hydro power Nigeria ICRC PPP Platform. https://ppp.icrc.gov.ng>project

[5] Ajao, K. R., Ajimotokan, H. A., Popoola, O. T. and Akande, H. F. "Electric Energy Supply In Nigeria Decentralized Energy Approach", New York Science Journal http://www.sciencepub.net/newyork, ISSN 1554- 0200, 2(5), 2009, pp. 84-92.

[6] Sambo, A.S."Renewable Energy Electricity in Nigeria: The Way Forward", Renewable Electricity Policy Conference Held at Shehu Musa Yar'adua Centre, Abuja, Nigeria, 2006

[7] Aliyu, U. O. and Elegba, S. B. "Prospects for Small Hydropower Development for Rural Applications in Nigeria", Nigerian Journal of Renewable Energy 1, 1990, pp. 74-86

[8] Akanmu J.O., and Ezeh E.M. "Small hydropower development: A solution to achieve Millennium Development Goals (MDGs)", paper presented at a Stakeholders Workshop, organized by the Energy Commission of Nigeria, 2005.

[9] www.waterboards.ca.gov/waterissues/programs/swamp/docs/cwt/guidance/5 13.pdf

[10] Hassan, Y.G. and Abdulhamed, A.I."Analysis of trends in monthly rainfall profile for Katsina, Katsina state (1946-2006)", The Zaria Geographer Vol. 19, No 1, 2012, pp 111- 123

[11] Colorado Energy Office: Small Hydropower Handbook, Kurt Johnson and Andrea Hart 1973.

[12] Harvey et al, "Micro hydro power design manual" Intermediate technology development group. (ITDG). 1993, UK.

[13] S.G Zaku, A.Kabir,A.A.Tukur and Jimento I.G. "Wood fuel consumption in Nigeria and the energy ladder: A review of fuel wood use in Kaduna State". Journal of petroleum Technology and Alternatives Fuels vol 4(5),pp.85-89, May 2013. 